\title{
Comparative Study of Wood Consumption in Structures of Concrete Roof
}

\author{
Antônio Carlos dos Santos Ribeiro ${ }^{1}$, Roberto Vasconcelos Pinheiro ${ }^{1}$, Laurenn Borges de Macedo ${ }^{2}$, \\ André Luis Christoforo ${ }^{3, *}$, Francisco Antonio Rocco Lahr $^{4}$ \\ ${ }^{1}$ Department of Civil Engineering, State University of Mato Grosso (UNEMAT), Sinop, Brazil \\ ${ }^{2}$ Department of Materials (SMM), São Paulo University (EESC/USP), São Carlos, Brazil \\ ${ }^{3}$ Centre for Innovation and Technology in Composites - CIT ${ }^{\mathrm{C}} \mathrm{C}$ 'Department of Civil Engineering (DECiv), \\ Federal University of São Carlos (UFSCar), São Carlos, Brazil \\ ${ }^{4}$ Department of Structural Engineering (SET), São Paulo University (EESC/USP), São Carlos, Brazil
}

\begin{abstract}
Several factors suggest wood use in construction field and, among them, highlight mentioned material's versatility and availability, widely used in roof structures. In some situations, carpenters are responsible for implementing these structures and are almost never designed according to normative precepts. This study shows relation between timber volume and construction area (in plain view) with concrete roof structures and spans ranging from 8 to 14 meters, with bolted connections, relative to C30 strength class, from standard ABNT NBR 7190 recommendations. Based on these values, it is presented a comparison about consumption usually obtained by active technical professionals in Sinop - Mato Grosso State, Brazil, from a study case of a shed in Forest Park of Sinop. Results show a mean consumption of $0.025 \mathrm{~m}^{3} / \mathrm{m}^{2}$ for the considered span. Thus, there was a $21 \%$ decrease in timber volume (span of $14 \mathrm{~m}$ ) and $50 \%$ in raw material (timber) coast when compared mentioned park structure. Covers projects were made with C30 species, about 30\% less resistant than employed in the shed. In addition, there was a 50\% reduction in pillars and foundations number compared to shed.
\end{abstract}

Keywords Roof structures, Concrete roof, C30 strength class, Relation between timber volume and building area

\section{Introduction}

Currently, in the Amazon Forest, it's estimated more than four thousand tree species, according to [1]. However, deforestation is still an alarming and aggravating factor.Through data from National Institute for Space Research (INPE) and Monitoring Project of Amazon rainforest by Satellite - PRODES, point out, initially,an increase of $28 \%$ of deforestation in year of 2013 compared to 2012, even after four years of successive falls.

It is well-known that forest resources abuse can come to cause shortage, even in such abundant material like wood. Reforestation as well as smart and sustainable use through well-designed projects and managements are solutions that can reduce uncontrolled deforestation tendency. But still, there are other impasses regarding timber misuse, on structures, in Brazil.

This fact is corroborated by poor training provided by some superior education institutions, to civil engineers, in timber area. This causes a unprepared in application of this material, and in timber structures projects preparation,

* Corresponding author:

alchristoforo@gmail.com (André Luis Christoforo)

Published online at http://journal.sapub.org/ijme

Copyright (C) 2016 Scientific \& Academic Publishing. All Rights Reserved jeopardizing structure functioning [2].

Wood for structural purpose competes directly with other structural materials, although there is still some concern in their use, especially by ignorance of its physical and mechanical properties [3].

Regarding to wood application in structures, it is observed that for certain roofing types, trusses are often used for technical solutions (carpenters), by wood sector businessmen and even higher education professionals (civil engineers). This structural scheme applicationis a natural tendency, however, they did not adopt [4]: Timber Structures Project, Brazilian Association of Technical Standards ABNT, as a reference.

The aim of this work is to present wood consumption, from projects development of truss structures with two inclinated planes(concrete roof) and spans ranging from eight, 10, 12 and 14 meters, employing species of strength class "C-30" [4]. As a byproduct, it was also carried out a case study (mapping), for wood consumption of a truss structure (ceramic tiles) existing, with 14 meters span.

Finally, this study compared results field, for professionals in the civil construction field, with those obtained from procedures recommended by [4]. These results are presented through wood consumption rates in relation to building area, as relationship $" \mathrm{~m}^{3 /} \mathrm{m}^{2 "}$ according to projects development and from case study (structure 
already executed).

\section{Theoretical Fundaments}

\subsection{Wood}

According [5], wood used in construction are distinguished into two main categories. First is angiosperm class, which is fall within by dicots also known as hardwoods. Second is Gymnosperm class, which includes Conifers, known as softwoods.

According to [6], a great advantage of timber can be considered that wood is a lightweight structural material, due its internal fibrous structure. Durability, as well as the fire performance - despite being a flammable material - is also other important properties, according to the cited authors.

[5] says that timber is easy to handle, to define its forms and dimensions. Since its acquisition in log form to its unfolding is a relatively simple process with no need for an accurate technology, not requiring an industrial process because material comes ready to use, requiring only finish.

[2] says that comparing typical wood values with conventional concrete, it is observed that, in general, woods are more resistant.

Also, wood use is justified due to various favorable characteristics such as aesthetics, thermal comfort and, especially, low power consumption required for unfolding. Added to this, timber becomes not only advantageous by low carbon dioxide consumption forward to these other materials cited, as well as by absorbing it during tree growth phase [7]. According to author, these peculiarities added to environmental issues, wood is viewed as a material with potential to remove large carbon dioxide amounts from atmosphere.

Layman believes that timber use causes devastation in forests, but we must remember that wood is a renewable material and, in addition, during its growth, tree consumes nature impurities, turning them into woody material [6].

Wood used in Brazil is for multiple purposes. In civil construction, timber stands out for its solution to problems of structures, bridges, silos and power lines. In furniture industry, as well as in the packaging also uses wood and its derivatives [8].

In fact, from foregoing, it is clear that misinterpreted is wood. Hence, it can be concluded that there are two extremely important factors that contribute to wood non-use in Brazil, that is, culture and ignorance of its properties, for much of Brazilian professionals.

\subsection{Standardization}

For structural elements dimensioning of roof, it is necessary following normative documents:

[4] - "Timber Structures Design";

[9] - "Loads for building structures calculating";

[10] - "Forces due to wind in buildings";

[11] - "Actions and safety in structures - Procedure".

\subsection{Wood Properties}

Knowledge and understanding of wood physical and mechanical properties are needed for better sizing and subsequent material use [2]. Such properties are influenced by various factors such as temperature different conditions, composition, and soil moisture in tree growing site, population density and type of management employed, as well as tree position in field and rainfall [1].

Aforementioned properties, density, strength, stiffness or modulus of elasticity and moisture, are the most relevant to wood structural elements design [3].

\subsubsection{Physical properties}

It is extremely important to know wood physical properties, because these significantly influence in performance and strength of wood used in structures. According [7], they are: moisture content; density; dimensional stability (swelling and swelling).

\subsubsection{Mechanical Properties}

Mechanical properties are divided into elasticity properties and strength. Wood anatomical elements provisions and compositions (cellulose chains) are responsible for mechanical strength [8].

\section{Elasticity:}

Elasticity is understood as material ability to assume its original shape after removal external action that requested, without presenting residual deformation.

Modulus of elasticity values defined in according to type and direction of solicitation in relation to fibers, such as: longitudinal (compression and tension parallel to fibers, bending and compression perpendicular to fibers); transversal [2]. According to [4], longitudinal modulus of compression parallel to fibers is adopted as reference value.

\section{Strength:}

[4] states that strength is material ability withstand stresses. Wood strength is expressed by following effects: compression (parallel and normal compression and inclined compression relative to fibers), tension (normal and parallel tension to fibers), shear (longitudinal and parallel to fibers), impact in bending, cracking and hardness [3], tenacity or the critical energy release rate as mechanical fracture parameter of wood [12, 13] and the viscoelastic behavior of wood [14]. Cracking and hardness properties are used as quality parameter [5].

\subsubsection{Another Material Properties}

\section{Organoleptic properties:}

Organoleptic properties are related to decorative and ornamental value of work. These properties are: color; smell; taste or flavor; texture.

Natural resistance:

[15] states that durability of wood with respect to biological attacks depends on species, but low natural 
resistance of some species is easily compensated by preservative treatments (industrial and home) adequate.

Following figure shows pathologies arising of xylophages' organisms attack.

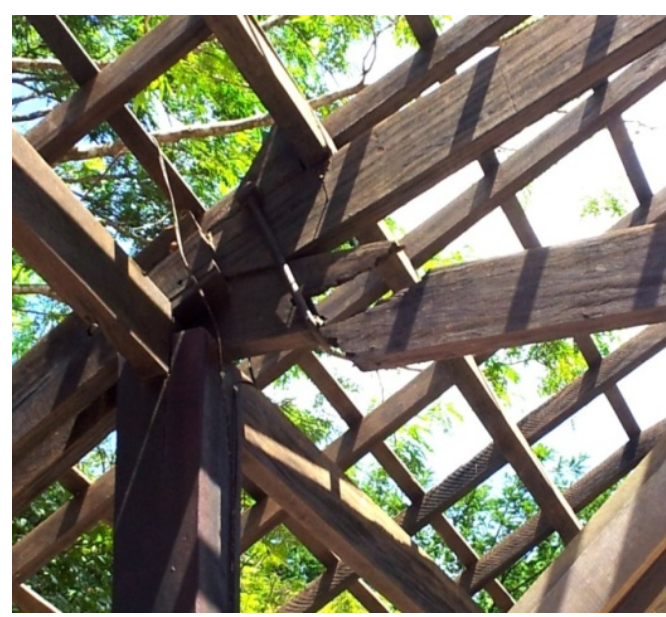

Figure 1. Lower flange - Shed Forest Park of Sinop - MT

Fire resistance:

According [15], in general, wood properties knowledge lack, considers, erroneously, as a low fire resistance material. However, any parts fire-exposed initially acts as fuel for spread of flame, however, after several minutes, portion exposed to flame, it is carbonized, thus resulting in a heat insulating for rest of the part. Thus, it assists in heat contention and therefore prevents further damage to structure. This situation is demonstrated in Figure 2.

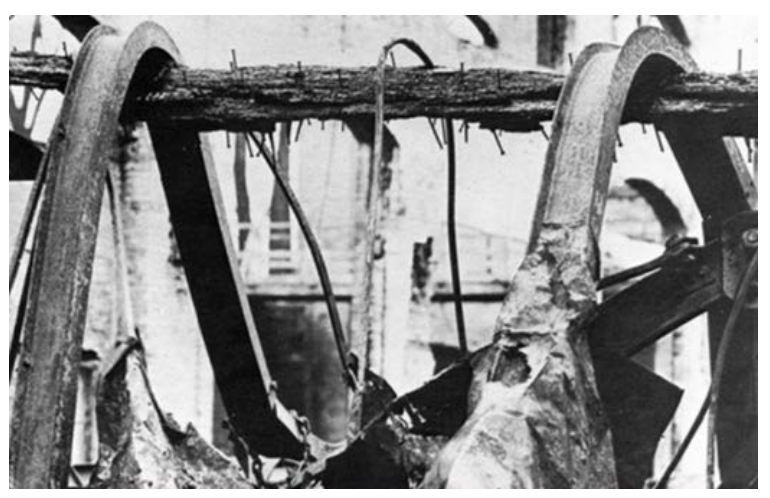

Figure 1. Fire resistance. Source: [116]

\subsection{Timber Structures}

For development of structural design, in principle, it is defined the most appropriate structural system, as well as the most suitable species.

\subsubsection{Structural Conception}

Truss flat:

Trusses type "Howe", "Pratt" and "Fink ("W") are commonly employed, but traditionally in Brazil, it is employed truss structures in wood type Howe. Such roof structures (Figure 3), also called by scissors have function of supporting roofing and its joist hangers of support [5].
Trusses, by definition, have straight bars, nodes (bars intersection points) are considered ideal connections (perfect joints - absence of bending moments and cutting effort) and all actions are applied to nodes. Main elements of truss type "Howe" are:

- Upper chord: structure upper contour, works as supports of purlins and, usually, their bars are subjected to normal compressive forces, coming from dead and moving loads as wind actions.

- Lower chord: inferior edge of the truss, usually tensioned under dead and moving loads as wind actions;

- Webs: pieces that connect upper and lower chord bars;

- Diagonal: inclined pieces that connect upper and lower chord, usually lying in oblique positions.

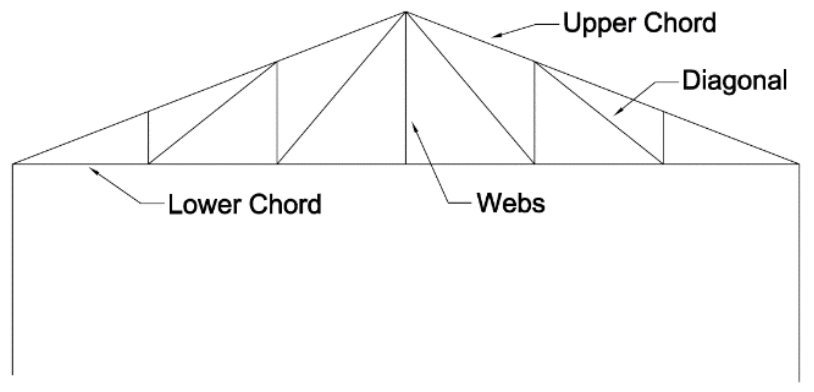

Figure 2. Nomenclatura dos elementos das treliças. Fonte: Adopted from [17]

\section{Roofcomponents:}

Elements which make up woodwork of a roof structure are:

- Purlins: elementlsupported on two successive scissors or prop and receive loads directly from the tile (steel roof, fibro-cement, etc.). Span (distance between the scissors) depends on cross section dimensions of static scheme, wood type and tile used.

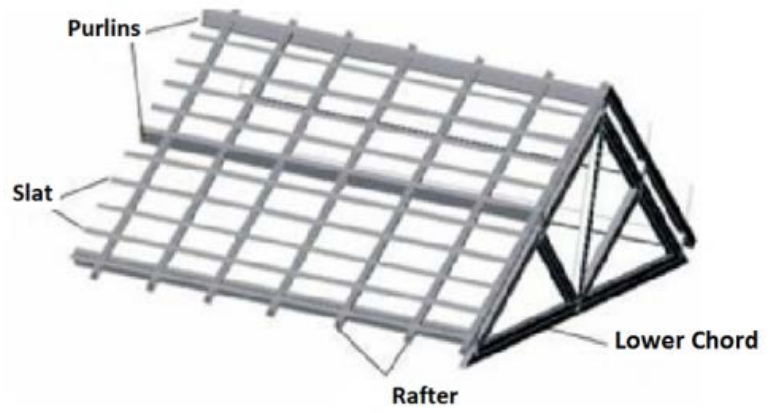

Figure 3. Timber roof components. Source: Adopted from [17]

\section{Connections:}

[4] reports that can be used three types of connections for structural wood piece, which are: metal pins (nails, bolts and screws), timber dowels, gang-nail plates and metal connectors (metal rings). In Brazil, metal pins (screws and nails) are the most used, while in the USA, Oceania and Europe, where it employs prefabricated truss structures are adopted-connections through plates with printed teeth. 


\section{Concrete roof:}

Main characteristics and specifications of these tiles: dead load, tightness, among others, are given in manufacturers catalogs.

\subsubsection{Actions and Loading}

In design procedures, the most critical situation in which structure will be subject should be considered and, therefore, actions should be combined considering simultaneous incidence possibility.

Loads:

Normative documents [11] - "Actions and security in structures - Procedure "[9] - "Loads for building structures calculating" and [10] - "forces due to wind on buildings", define and discriminate active actions types in buildings. For a specific approach, actions relating to wind, own weight (structural and non-structural) and bracing, will be presented as follows.

\section{Wind:}

[10] states that forces on a structure resulting from wind static and dynamics action effects, must be calculated separately for:

- Structure as a whole;

- Structures parts (roof, walls, etc.);

- Sealing elements and their anchorages (tiles, glass,

window frames, sealing panels, etc.).

- Own weight (structural and non-structural).

According to [4], permanent action (structural) refers to woodwork's own weight, with $3 \%$ increase, to consider elements and connections devices effect (nails, screws, plates, hats, etc.). Regarding tile (nonstructural permanent action) is obtained from manufacturer's information.

\section{- Bracing}

Bracing system is positioned perpendicular to trusses (Figure 5), improving load sharing between them, reducing potential vibration problems in structure and, in addition, it develops a three-dimensional structural system. That system is able to withstand wind actions and, prevent loss of local and global stability, reducing buckling lengths outside of trusses vertical planes [5].

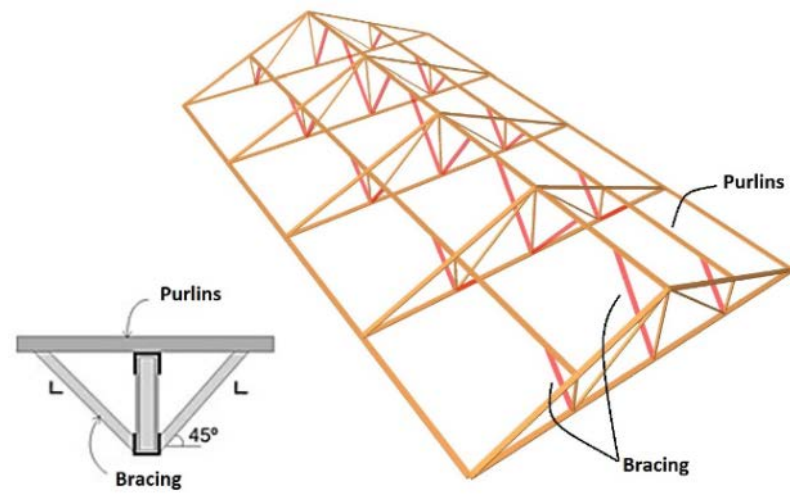

Figure 4. Lateral bars acting as vertical bracing in structure. Source: Adopted from [18]

\section{Loading:}

Loading term is defined as actions combinations, with simultaneous occurrence non-negligible probability.

[11] states that during construction life can occur four different loads types, being these: Normal; special; exceptional; construction.

\subsubsection{Dimensioning}

[7] below describes the procedure for appropriate truss dimensioning:

"In general, initial procedure to be made when dimensioning a timber truss is its geometry determination. Next step consists in determining distance "between trusses" in building length direction, which can be done by purlin dimensioning to oblique bending, or even from distance imposition "between trusses", predefined, to which should be checked ultimate limit state and purlin use. Subsequently, truss must be loaded with permanent actions and variable, and stresses generated in structural elements (chords, diagonals and webs); due to these actions must be combined so that each structural element dimensioning, including those that comprise bracing system be done for combined effort condition acting in each case. Screws number in each truss node is determined, then it is done structural members and connections detailing, quantification of structure final weight and, finally, presentation of a material list. "

Dimensioning of timber elements and connections are given from ultimate limit state, while verification of excessive displacement is given from Service Limits States (Use).

\section{Ultimate Limit State - structure}

These states occurrence determines stoppage of all or part of structure. To verify security of timber structure, as set by [4] - item 7, is need consider the following ultimate limit states:

- Strength: compression parallel to fibers (short pieces); inclined compression to fibers; compression perpendicular to fibers; parallel tension to fibers; bending (simple and oblique); bending-compression; bending-tension; shear parallel to fibers;

- Local stability: compression parallel to fibers (averagely willowy pieces or willowy); bending;

- Global stability: bracing.

Service Limit State - connections:

Connections dimensioning between wood pieces, is given as set forth by [4]- item 8 and, states that should not be taken into account friction between contact surfaces and neither efforts transformed by stirrups, respecting particular spacing so it can avoid wood splitting. For dimensioning criteria, it is employed the following ultimate limit state:

- Strength: embedment parallel and normal to fibers (wood); runoff (metal pins).

Service Limits State- verifications:

To verify timber structure safety, as provided in Section 
9.1.1 and 9.1.2 from [4], it is needed to consider the following limit states:

- Excessive deformations that affect structure use or aesthetics;

- Damages in non-structural materials of construction resulting from deformation thereof;

- Vibrations excess.

Finally, beyond consideration of last limits states and service, it should consider classification of timber parts [4] (item 10.6), and how to precede the preventive treatments [4] (item 10.7) to avoid piece deterioration, as well as ensure structure ease of water drainage and aeration.

\section{Material and Methods}

\subsection{Materials}

Materials employed to study development were:

Didactic material and normative documents;

Software to support in normal forces and displacements determination.

Software to support at preparation of spreadsheets and graphs.

\subsection{Methods}

\subsubsection{Case Study}

From on-site inspection, it was mapped information relevant for study.

\subsubsection{Actions, Loadings, Internal Efforts and Design Parameters}

Actions and loadings definitions were carried out based on following normative documents: [4], [11], [9] and [10]. For obtaining efforts on structures bars, as well as displacement of same, it was used Ftool software, developed by Professor Luiz Fernando Martha, PUC-Rio - Pontifical Catholic University of Rio de Janeiro. AutoCad software were also used, for trusses design (cross sections and plant) of each spam.

\subsubsection{Dimensioning and Verification}

Timber elements dimensioning of (battens, rafters, purlins, truss, bracing), of bolted connections, and arrows check (battens, rafters, purlins and trusses), was based on normative prescriptions [4]. To expedite process, parts dimensioning that make up structure, were done with spreadsheet from MS Excel software.

\subsubsection{Technical Parameters}

Relationship " $\mathrm{m}^{3} / \mathrm{m}^{2}$ " was defined from projects results and according to case study (structure already executed forest park shed of Sinop - MT). The same were presented as graphs.

\subsubsection{Preservation}

According to descriptions given in Annex D.3.3 of [4], minimum preservation for dicotyledonous species should be through brushing process. In a practically way and from manufacturers' recommendations, two preservative coats of product are used in parts.

\subsubsection{Bracing}

Trusses bracings systems are arranged on roof and lower stringer plan. On Roof plan, along with purlins, $10 \mathrm{~mm}$ steel bars with turnbuckles, in "X" form. For horizontal plane, rigid bars were employed (section type "T": $4 \times 20 \mathrm{~cm}$ soul; $2,5 \times 20 \mathrm{~cm}$ table) joining lower strings nodes of adjacent structures, and between such parts were located $10 \mathrm{~mm}$ steel bars with turnbuckles in " $\mathrm{X}$ " form. For local bracing (Trellis bars), stiffeners were proposed with $45 \mathrm{~cm}$ spaced, for compressed bars and $1.25 \mathrm{~m}$ to tensioned bars, according to [4].

\section{Results and Discussion}

\subsection{Presentation and Result Analysis}

\subsubsection{Case Study}

Forest Park shed located in Sinop city - MT was case study object for purposes of comparison with elaborate designs in accordance with relevant normative documents. According [19], from on-site inspection, it was obtained:

- truss type "Howe": superior/lower strings $(5 \times 15 \mathrm{~cm})$; webs $(2 \mathrm{pc} 2,5 \times 15 \mathrm{~cm})$; central web $(5 \times 15 \mathrm{~cm})$ and diagonal $(5 \times 10 \mathrm{~cm})$;

- purlins $(5 \times 15 \mathrm{~cm})$; rafters $(5,0 \times 6,0 \mathrm{~cm})$; battens $(2,5 \times 5,0 \mathrm{~cm})$;

- spacing between trusses: 2,5 meters

- spacing between battens: $32 \mathrm{~cm}$;

- spacing between rafters: $50 \mathrm{~cm}$.

- dimension: 14 meters (width) and 32,5 meters (length). Figure 6 shows referred shed.

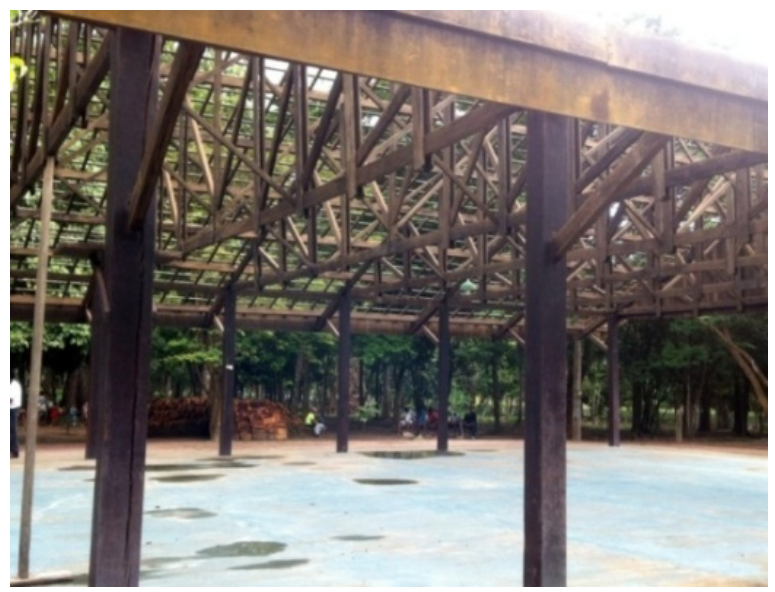

Figure 5. Forest park shed of Sinop - MT 
Based on information and with spreadsheets aid, wood volume consumed quantitative compared to built area was generated.

Table 1. Forest park shed $\mathrm{m}^{3} / \mathrm{m}^{2}$ relation

\begin{tabular}{cccc}
\hline Description & Volume $\left(\mathbf{m}^{3}\right)$ & Área $\left(\mathbf{m}^{2}\right)$ & Relation $\left(\mathbf{m}^{3} / \mathbf{m}^{2}\right)$ \\
\hline Results & 14.42 & 455 & 0.032 \\
\hline
\end{tabular}

\subsubsection{Timber Structure Projects}

Projects were developed, according to recommendations issued by [4], with following characteristics:

- structures type "Howe" and spans (between support axes) of $8,10,12$ and 14 meters;

- length: 35 meters;

- spacing between trusses: 5 meters;

- trusses elements (8 meters span): superior/lower strings (2 pc. $2.5 \times 10 \mathrm{~cm})$; diagonal (2 pc. $2.5 \times 10 \mathrm{~cm})$, web (1 pc. $5 \times 11 \mathrm{~cm})$;

- Trusses elements (spans 10, 12 and 14 meters): superior/lower strings (2 pc. $2.5 \times 15 \mathrm{~cm})$; diagonal (2 pc. $2.5 \mathrm{x} 15 \mathrm{~cm})$, web $(1 \mathrm{pc} .5 \mathrm{x} 11 \mathrm{~cm})$;

- eaves purlins: "T" type (soul - 4x20cm; table $2.5 \mathrm{X} 15 \mathrm{~cm})$

- intermediate/ridge purlins: "T" type (soul - 4x20cm; table - 2,5X5cm);

- static scheme (purlin): bi-supported;

- static scheme (intermediate/ridge purlins): continuous, with internal support, through lateral bars;

- rafters: rectangular $(5 \times 6) \mathrm{cm}$ spaced every $70 \mathrm{~cm}$;

- battens: rectangular (2x5) cm, spaced on average every $32 \mathrm{~cm}$.

- "Concrete" tile;

- Bolted connections "Wood / wood" to 8 and 10 meters spans;

- Bolted connections "wood / steel sheet Gusset type" for12 and 14 meters spans;

\section{Relation $\mathrm{m}^{3} / \mathrm{m}^{2}$}

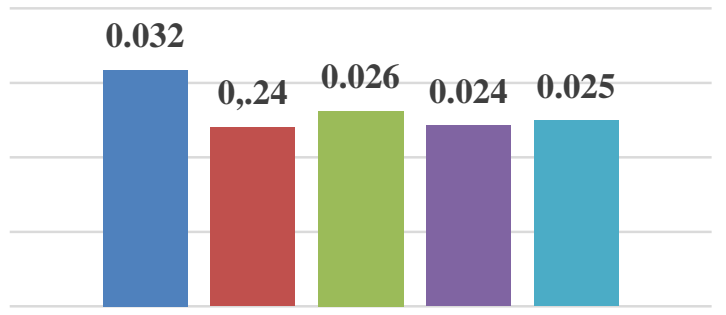

$$
\begin{aligned}
& \text { P. Florestal - Vão de } 14 \mathrm{~m} \\
& \text { Projeto - Vão de } 08 \mathrm{~m} \\
& \text { Projeto - Vão de } 08 \mathrm{~m} \\
& \text { — Projeto - Vão de } 08 \mathrm{~m} \\
& \text { — Projeto - Vão de 08m }
\end{aligned}
$$

Figure 7. Relation $\mathrm{m}^{3} / \mathrm{m}^{2}$ of projects and forest park
- Strength class: dicotyledonous (C30).

From above information, relationship $\mathrm{m}^{3} / \mathrm{m}^{2}$ results of projects were obtained, as shown in Table 2.

Table 2. Relationship $\mathrm{m}^{3} / \mathrm{m}^{2}$ of proposed projects

\begin{tabular}{cccc}
\hline Span $(\mathbf{m})$ & Volume $\left(\mathbf{m}^{3}\right)$ & Área $\left(\mathbf{m}^{2}\right)$ & Relation $\left(\mathbf{m}^{3} / \mathbf{m}^{2}\right)$ \\
\hline 8.0 & 6.72 & 280 & 0.024 \\
10.0 & 9.19 & 350 & 0.026 \\
12.0 & 10.19 & 420 & 0.024 \\
14.0 & 12.21 & 490 & 0.025 \\
\hline
\end{tabular}

Figure 7 shows values described in Table 1 and Table 2 .

For Itaúba (Mezilaurus itauba), mean market value is US\$ $700 / \mathrm{m}^{3}$, while Cupiúba (Goupiaglabra) is being sold at a mean value of US $\$ 500 / \mathrm{m}^{3}$. Table 3 shows relation coast of wood species of Itaúba and Cupiúba, from market research in Sinop city - MT.

Table 3. Cost comparison between project and case study

\begin{tabular}{cccc}
\hline Description & Volume $\left.\mathbf{( m}^{\mathbf{3}}\right)$ & Cost by $\mathbf{~ m}^{\mathbf{3}}$ & Total cost (US\$) \\
\hline Shed Forest Park & 14.42 & 648.64 & 9353.50 \\
Span of $8(\mathrm{~m})$ & 6.72 & 351.35 & 2361.10 \\
Span of $10(\mathrm{~m})$ & 9.19 & 351.35 & 3228.90 \\
Span of $12(\mathrm{~m})$ & 10.19 & 351.35 & 3580.27 \\
Span of $14(\mathrm{~m})$ & 12.21 & 351.35 & 4290.20 \\
\hline
\end{tabular}

Figure 8 shows values described in Table 3 for better representation.

\section{Total cost for each situation}

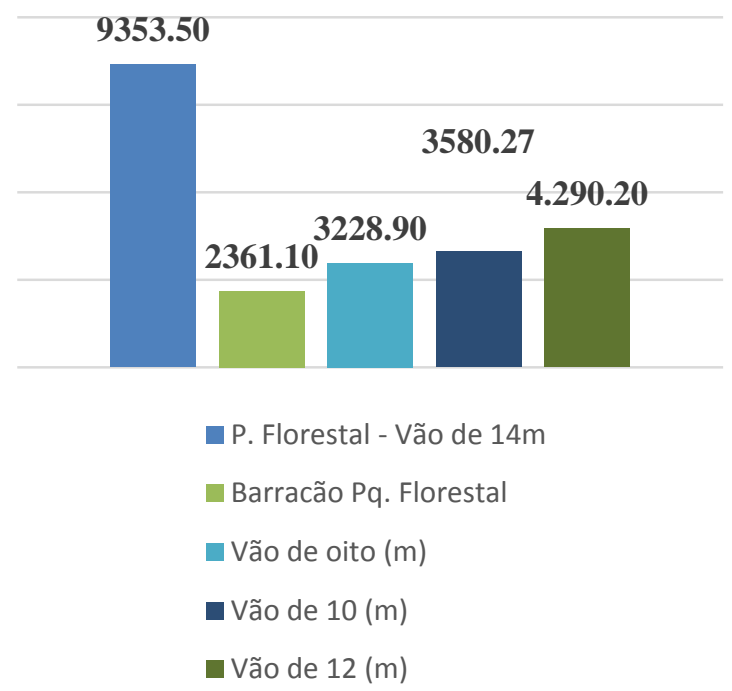

Figure 6. Cost comparison between project and case study

\section{Conclusions}

From results obtained, following conclusions are presented:

i) A mean consumption rate for proposed projects, equal to $0.025 \mathrm{~m}^{3} / \mathrm{m}^{2}$ for $8,10,12$ and 14 meters spans and a consumption rate equal to $0.032 \mathrm{~m}^{3} / \mathrm{m}^{2}$ for span of 14 
meters of Forest Park shed were observed. Thus, a reduction in the volume of wood was around $20 \%$.

ii) A coast variation from $\mathrm{R} \$ 9353.50$ to $\mathrm{R} \$ 4290.20$ for structure of $14 \mathrm{~m}$, resulting in raw material (wood) reduced cost, approximately $50 \%$, was observed;

iii) Projects were defined spans, between trusses, equal to 5.0 meters, while in case study, span is 2.5 meters. Thus, a $50 \%$ reduction was observed in infrastructure (pillars) and foundations;

iv) Ceramic roof Weight (Forest Park) observed is approximately $44.8 \mathrm{~kg} / \mathrm{m}^{2}$, while concrete roof (proposed structures) has $49.0 \mathrm{~kg} \mathrm{/} \mathrm{m2.} \mathrm{This}$ demonstrates a load increase capacity at around 9\%;

v) Forest Park building was constructed with Itaúba species - Mezilaurus Itauba (Meisn) - strength classes C40/C60, while proposed projects were designed for wood species with C30 strength class. Therefore, it is worth mentioning that projects in question was dimensioned for species about 30\% less resistant than that used in the shed;

Faced with foregoing, it is evident importance of developing a timber structure design, targeting pursuit of quality, durability and safety. Furthermore, technical feasibility of strength class C30 wood species applying in roof structures was verified, as well as relief provided to environment through reduction of wood volume and pressures on deforestation and law species employment.

\section{REFERENCES}

[1] Góes, J. L. N. de. Estruturas de Madeira (Dimensionamento). Apostila para o curso de Engenharia Civil. Centro Universitário UNILINS. Lins, SP. 2006. 91p.

[2] Gesualdo, F. A. R. Estruturas de Madeira (Notas de Aula). Apostila para a faculdade de Engenharia Civil. 2003. 92p. Universidade Federal de Uberlândia.

[3] Calil Junior, C. et al.; SET 406 - Estruturas de Madeira: Notas de Aula. Apostila para a disciplina de Estruturas de Madeira. 1998. 107p. Universidade de São Paulo, escola de Engenharia de São Carlos/USP.

[4] Associação Brasileira de Normas Técnicas. NBR 7190. Projeto de estruturas de madeira, Rio de Janeiro, 1997. 107p.

[5] Pfeil, W.; Pfeil, M.; Estruturas de Madeira. $6{ }^{\text {a }}$. Ed. Rio de Janeiro: LTC, 2003. 224p.

[6] Brito E Silva, M. C. Estruturas de Madeira. Departamento de
Artes e Arquitetura. 2010. 34p. Pontifícia Universidade Católica de Goiás, Goiânia.

[7] Calil Junior, C.; Molina, J. C. Coberturas em estruturas de madeira: exemplos de cálculo. $1^{\text {a }}$ ed. São Paulo: Pini, 2010. 214p. FSP. Pesquisa: Desmatamento na Amazônia Sobe 28\% em 2013. Notícia. novembro, 2013. Disponível em: $<$ http://www1.folha.uol.com.br/ambiente/2013/11/1371434desmatamento-na-amazonia-sobe-28-em-2013.shtml>. Acesso em: 08 março 2014.

[8] Calil Junior, C.; Lahr, F. A. R.; Dias, A. A. Dimensionamento de Elementos Estruturais de Madeira. Barueri, SP: Manole, 2003. 149p.

[9] Associação Brasileira de Normas Técnicas. NBR 6120. Cargas para cálculo de estruturas de edificações, Rio de Janeiro, 1980. 6p.

[10] Associação Brasileira de Normas Técnicas. NBR 6123. Forças devidas ao vento em edificações, Rio de Janeiro, 1988.

[11] Associação Brasileira de Normas Técnicas. NBR 8681. Ações e segurança nas estruturas - Procedimento, Rio de Janeiro, 2003. 15p.

[12] Moutou Pitti R., Alaa C. Statistical approach and reliability analysis for mixed- mode applied to wood material. Wood Science and Technology. 46(6), 1099-1112, 2012.

[13] Moutou Pitti R., Dubois F., Pop O., Absi J. Finite element analysis for mixed mode crack growth in viscoelastic orthotropic medium. International Journal of Solids and Structures. 46 (20), 3548-3555, 2009.

[14] Toussaint E., Fournely, E., Moutou Pitti, R., Grédiac M. Studying the mechanical behavior of notched wood beams using full-field measurements. Engineering Structures. Vol 113, 277-286, 2016. DOI: 10.1016/j.engstruct.2016.01.052

[15] Szücs, C. A. et al.; Estruturas de Madeira. Departamento de Engenharia Civil. Universidade Federal de Santa Catarina. Florianópolis, 2008. 199p.

[16] Ritter, M. A.; Timber Bridges. Forest Products Laboratory. Forest Service. Madisson, 1990.

[17] Meirelles, C. R.; Pala, A. Apostila: Processo Construtivo em Madeira. Faculdade de Arquitetura e Urbanismo. Universidade Presbiteriana Mackenzie. 2010. 67p.

[18] CBCA; Centro Brasileiro de Construção em Aço: Dimensionamento de estruturas de aço. 05 maio 2015. Diponível em: <http://cursoscbca.netpoint.com.br/moodle/cu rsos/DimensionamentoEstruturaAco/Modulo3/4.html.bkp> Acesso em: 05 maio 2015.

[19] Ferreira, G.; Pinheiro, R. V. Patologias em estrutura de madeira para cobertura: estudo de caso de edifício parque florestal de Sinop - MT. Universidade do Estado de Mato Grosso. Sinop, 2015. 9p. 